\title{
Challenges and Ways Forward in Teaching Reading: Case Studies of Low Socioeconomic Multicultural Schools
}

\author{
Jo Fletcher \\ University of Canterbury \\ New Zealand
}

\begin{abstract}
Reading is a key skill needed to communicate effectively in today's world. The changing landscape of the ways people communicate using digital technologies is challenging schooling to provide contextually relevant learning for the wide range of students in schooling within New Zealand, and internationally. Students who are situated in the low socioeconomic areas can be further disadvantaged in learning to read by less resources and opportunities afforded to them in their everyday life experiences. Furthermore, when the education system has been established on Eurocentric models of learning, for Indigenous students or those from multicultural backgrounds, the values and knowledge underlying the teaching and learning can lack relevance. This article explores what is happening in New Zealand schools located in low socioeconomic multicultural areas. The focus is on young adolescent students and how reading instruction is impacting on their learning. Interviews were conducted with principals, teachers, students and parents to gain an understanding of their perceptions. The study uncovered that although there was a sincere commitment to the students, there were some disconnects between the home and school partnerships and a lack of focus on professional development in reading. However, two of the schools had been engaged in sustained three-year elearning professional development
\end{abstract}

\section{Introduction}

In New Zealand, there continues to be a significant percentage of students who are not engaging and motivated to learn to read. Regardless of ongoing schemes and literacy strategies initiated by the New Zealand Ministry of Education to tackle the underachievement in reading of these students, there has been little change [1]. Also, internationally reading achievement of students in countries such as Australia and England have significant percentages of low achieving students. This has been evident in the findings from the 2011 Progress in International Reading Literacy Study of 10-year-old students' reading achievement [1], [2], [3]. In New Zealand, more highly represented in this underachievement are Māori (Indigenous people of New Zealand), Pasifika (a term used to encompass students deriving from a range of Pacific Islands, such as Samoa, Tonga and Fiji), and children from low socioeconomic families [1]. For example, in New Zealand from 2001 to 2011, in the Progress in International Reading Literacy Study (PIRLS) of ten year-old students' achievement in reading there has been minimal noteworthy improvement in the mean scores of any of the four main ethnic groups (New Zealand European, Asian, Māori and Pasifika). Furthermore, even though students performed at variable levels in reading, irrespective of the socioeconomic status of their school region, approximately 50 percent of students in very low socioeconomic schools reached the PIRLS Intermediate International Benchmark, in comparison to 90 percent of their peers in high socioeconomic schools [1]. This disparity of 40 percent of 10 year old students in their reading achievement between very low socio economic schools compared to high socioeconomic schools in their reading achievement provides compelling evidence that the socioeconomic background of many students is influential. Arguably, those students in very low socioeconomic schools have less resources, such as access to books, digital technologies and wider life experiences. This can be part of the lived reality for parents who are on limited incomes, and/ or who are working extended hours at minimum wage levels.

Of interest, in the Progress in International Reading Literacy Study (PIRLS), in comparison to several other countries in Canada, only two percent of Canadian students did not reach the 'low international Benchmark' [4].

\section{Literature Review}

From a social constructivist perspective, the acquisition of effective reading skills and motivation to be a reader, are influenced by the personal and 
social interactions of learners [5]. Bronfenbrenner and Mahoney [6] maintained that learning and human development investigations which concentrate merely on the reading process skills can be restricted. To better understand what supports reading or can be the barriers to motivation and learning to read, require educators, school leaders and teachers to develop knowledge of what motivates children to want to read. Factors such as family and school partnerships, the professional development of the teachers, how relevant the resources used in reading instruction are to the real life and the cultural backgrounds of the readers, all play an important part of raising reading outcomes for all learners [7,8].

For many learners in today's highly digital social world, the boundaries of a school curriculum may be deemed by young adolescents as pre-digital, encompassing a teaching and learning philosophy that is unshakable and inflexible [9]. Furthermore, when digital technologies are included in the teaching and learning programs in schooling, this needs to be meaningfully planned and carefully implemented, rather than indiscriminate additions of assorted technologies to learning [10]. At worst, digital technologies can be used to keep students busy, but have little relevance to supporting the explicit learning needs of the students. Enriching learning across digital technology platforms by associating learning activities with a compilation of e-learning practices includes the careful development of a wellfounded, research informed pedagogical perspective along with supportive school leadership [11, 12].

The marginalised and disenfranchised of society are part of wider school communities. It is critical that schools are a share-able space that can nurture physical and emotional support for people from different cultures, beliefs and backgrounds. The social justice role of school leaders is to celebrate the different cultures, languages, diverse views and perspectives that the students in schools derive from [13]. Living in poverty is a cycle that can often span generations, making it challenging for an individual to break away from the expectations of family and society. The low socio-economic situations of families can affect the rate of physical and mental health issues, enduring poverty, poor nutrition, financial hardship and educational outcomes $[14,15]$.

Sustainable livelihoods, incomes, adequate housing and good nutrition are basic human rights. Yet, within New Zealand, and internationally, this is far from the lived reality for many children and their families. Regrettably, in New Zealand this is particularly more prevailing for Indigenous Peoples, Māori. The ongoing historical trauma from the colonisation left many Māori with dramatically changed circumstances in respect of wellbeing, sustenance and nutrition [16]. These circumstances continue into the $21 \mathrm{st}$ century, not only in New
Zealand, but also in other colonized countries, such as Canada and Australia.

\section{Research objectives and methodology}

The aim, in this study, was to focus on how principals and teachers in three low socioeconomic schools were implementing strategies to raise reading outcomes. A qualitative approach was used to gain the perceptions of the participants in the case study schools. This allowed for context-dependent knowledge representations to better understand the lived realities within the purposefully selected lowsocio-economic, multicultural schools.

\subsection{The schools and the participants}

The multiple case study design of the research investigation explored the perceptions of four teachers, three principals, 19 students and five parents of 11- to 13-year-old young adolescent students about practices and attitudes in reading. The participants were from three New Zealand State schools.

School one is a city state primary school with students from 5-12 years of age. The parents were predominantly from working class backgrounds and quite culturally diverse. The parents were generally involved with activities and events at the school and supporting their own children. There was quite a changing school population with 80 children enrolled within a year and 60 children leaving from a school population of 196. There were 40 percent New Zealand European, 28 percent Māori, 25 percent Pasifika and 7 percent other cultural ethnicities.

School two is a city state intermediate school with children from 11 to 12 years of age and is situated near an industrial park area. The parents were from mainly lower socio economic backgrounds, with a number of parents on some form of benefit. There was a high proportion of solo parents, and a high proportion of families in distress, as well as more than the national average of transient families. On the other hand, there were some families where it was their $2^{\text {nd }}$ or $3^{\text {rd }}$ generation at the school. There were 173 students at the school, of which 61 percent were New Zealand European, 21 percent Māori, 14 percent Pasifika and 4 percent other cultural ethnicities.

School three is situated in the heart of an older industrial area of a large city. It is a state primary school with students from $5-12$ years of age. As a small school of 110 students, the principal and staff had endeavored to develop a family environment in a very high needs school. This was evidenced by a more stable school population, which allowed the teachers and principal to know the children on a longer term basis. There were 54 percent New Zealand European, 28 percent Māori, 15 percent Pasifika and 3 percent other cultural ethnicities 
The interviews with the 31 participants were approximately 40 minutes in length, were audiotaped and later transcribed. Pseudonyms have been used when reporting the findings.

\subsection{Data analysis}

The emerging themes were categorized into initial codes. Afterwards, open coding was implemented to consider the coding categories. Next, axial coding provided a second order of analysis where any links between themes and codes were identified [6]. This allowed for emerging ideas to be separated. The final stage used selective coding to highlight the core concepts that had reappeared during the course of the analysis.

\section{Findings}

The findings from this study are reported and discussed in themes.

\subsection{Home school partnerships}

Of the three case study schools, only one appeared to have developed an initiative to work alongside the parents and help them develop more effective strategies to support their children in reading. One parent explained:

I have just done the reading together workshop with Bella [syndicate leader] so I would put that into action with him too. That is a fantastic workshop. She facilitates the reading together workshop. I did it twice just so I got everything out of it. They had it twice last year and it has been offered once this year [for parents]. (Parent, School one)

These opportunities for parents to be tutored in effective strategies to support their children's reading were much appreciated. Although, the other two schools had not provided these chances, the parents were informed of their child's progress in reading on a regular basis. Programmes, such as Reading Recovery, were part of the school support mechanisms to support low progress readers. One parent, a low progress reader herself, was appreciative that her daughter was getting better support than her own experiences had been when she was a student.

Well, I was like Lillie [my daughter]. I was behind and when I got to high school. That's when I got my reading recovery, so it was a little bit too late. So it was quite good that when Lillie was before 6 or 7 [years of age] she had to do this reading recovery program. I think that was really great and that really helped her, and they still give it to this day. They have wee rewards in assembly and it is a great encouragement. (Parent, School three)

The teachers were keen to establish positive rapports with their students, but establishing connections with the parents of these young adolescents had many constraints. For example, many of the parents worked and were not readily available to be part of the extracurricular school activities.

The class is definitely on the lower socio economic scale. The parents are supportive as best they can be, but sometimes that is a bit of a struggle. They literally just said, we can't take a day off. It can be a bit of a struggle for class trips and stuff. I want to take them out and doing things, but if I can't get the parent numbers, I just can't do it. It is not that they don't want to come, it is that they can't afford to come. (Teacher, School two)

The challenge of being a teacher and supporting learning is that you are dealing with parents from all walks of life. For some students, their home-life posed many difficulties. At School two, the teacher reported that some of the students' parents were gang and exgang members and this posed challenges in negotiating this landscape in a positive and appropriate manner. The way this teacher negotiated these children's backgrounds in a supportive manner was through reading.

The class have done studies on articles in the paper about gangs. The boys were fascinated. Some children commented saying such in such is in a gang and wanted me to do this but I didn't really want to.

Highly disadvantaged urban environments have significant implications for schooling. Riley's [?] research in such environments, emphasizes the significant challenges faced by school leadership to build tolerance and cohesion in volatile communities which provides space for the realities of the disenfranchised and marginalised people in society.

\subsection{Use of digital technologies in supporting reading}

Although none of the schools had recent sustained professional development in reading, two of the three schools had been involved in a professional contract to enhance practices in using elearning.

We did the three-year contract. It finished at the end of last year. We now have classroom blogs and the kids have a Google account so they can work on their work at home as well as school. Cara [one of the teachers] is pretty clued up and she is our ICT hardware teacher. So she provides 
most of the technical support to start with and then we use a computer support company. (Principal, School 1)

Another principal explained how the students were using digital technologies to enhance their reading skills and learning in general.

There are lots of webpages that they hook into and use on a regular, nearly daily basis. Using the iPads, there are lots of apps that the teacher has downloaded that we have discussed and talked about and purchased with, of course, a bit of advice. (Principal, School 3)

The thrust of the intervention in using class blogs and other forms of digital technology was to make learning more contextually relevant to these young adolescents' own personal experiences. For example, the principal of School one explained:

Every class has a class blog and the teacher will put up links to the topics on that class blog and activities and the kids do it. That fosters that 24/7 learning environment. I know at the moment they are doing $T V$ shows and they are putting those TV shows up on the blog. TV shows about what has been happening in the school over the last two weeks. It is not about how well you can use a computer, it is about how well you can speak and use a script - it is the English curriculum. They know how to make a movie and know how to do that, but they can't speak in a clear voice.

At School two, the resourcing appeared to be lacking to develop practices that may have enhanced learning to read using digital technologies.

The whole ICT - the communication segment is a struggle to do as children are not able to transfer the information off the iPads to a wider audience be it home etc. There are no e-portfolios or anything like that. Or interaction with another school or the electronic whiteboard even. There are no blogs or that sort of thing that really accelerates learning. (Acting principal, School two)

The frustrations of not having the resourcing to adequately facilitate a learning environment that included functioning digital technologies and Internet connections placed the students at further disadvantage.

\section{Discussion and Conclusions}

At the three case study schools, standardized testing in reading informed teachers during the school year. However, the school leaders had not instigated any recent sustained literacy professional development. These three schools had significant percentages of Māori and Pasifika students, who are more highly represented as underachieving in reading, and the schools were situated in very low socioeconomic areas. Effective and sustained literacy professional development is imperative and should be mandated in schools where the most 'at-risk' students in reading are more highly represented.

The parents interviewed represented a crosssection of backgrounds, yet all wanted their children to succeed in reading. Many were aware of the achievement level of their child in reading. Nevertheless, although some of the teachers and principals shared ways they were attempting to build stronger connections between home and school, there was a complex overlay of factors that challenged progress in building these relationships. These included children with English as a second language and parents whose poor socioeconomic situations impeded their availability to participate in schooling opportunities with their children. The endeavors of one teacher to mediate gang pressures and affiliations of some students' parents in his class highlighted the wider influences of that school community. Also, tensions in wider-school communities were evident in profound social and economic disparities, with at times and unpredictable pressures amongst different groups in the wider school community. Constructing school communities with a sense of respect for others and an intrinsic trust in schooling and learning, necessitates school principals and teachers to be certain in the beliefs and moral values which underpin schooling and teaching, especially when confronted with challenging social issues. At two of the three schools there appeared to be some disconnects in the facilitation of focused, strategic and informed approaches to link the home and school.

\section{References}

[1] Chamberlain, M. PIRLS 2010/11 in New Zealand: an overview of national findings from the third cycles of the Progress in International Reading Literacy Study (PIRLS). 2014. Retrieved from http://www.educationcounts.govt.nz (Access date: 1 February 2015).

[2] Thomson, S., Hillman, K., Wernet, N., Schmid, M., Buckley, S., Munene, A, Highlights from TIMSS \& PIRLS 2011 from Australia's perspective. ACER, Australia, 2012. Retrieved from https://www.acer.edu.au/files/TIMSSPIRLS_Australian_Highlights.pdf (Access date: 12 May 2015).

[3] Twist, L., Sizmur, J., Bartlett, S., Lynn, L, PIRLS 2011: Reading Achievement in England: Executive Summary. Slough, Berkshire, 2012.

[4] Labrecque, M., Chuy, M., Brochu, P., Houme, K, PIRLS 2011 Canada in Context. Council of Ministers of Education, Toronto, Ontario, 2012. Retrieved from http://www.cmec.ca/Publications?Lists?Publications/attach ments/294/PIRLS_2011_EN.pdf (Access date: 8 June 2015). 
[5] Vygotsky, L. S, Mind in society: the development of higher psychological processes, Harvard University Press, Cambridge, MA, 1978.

[6] Bronfenbrenner, U., \& Mahoney, M. (Eds). Influences on Human Development. Hinsdale, Illinois: Dryden Press, 1975.

[7] Charmaz, K., Grounded theory in the $21^{\text {st }}$ century: Application for advancing social justice studies. In N. K. Denzin \& Y. S. Lincoln (Eds), The Sage handbook of qualitative research ( $3^{\text {rd }}$ ed., pp 507-536). Sage, Thousand Oaks, 2005.

[7] Dempster, N., et al. (2012). Principals as literacy leaders; Confident, credible and connected. 2012,Kingson, ACT: Australian Primary Principals Association. Retrieved from http://www.appa.asn.au/wpcontent/uploads/2015/08/PALL .pdf

[8] Fletcher, J., M. Grimley, J. Greenwood, J. and F. Parkhill, "Raising reading achievement in an 'at risk', low socio-economic, multicultural intermediate school." Journal of Research in Reading, 2011, 36(2), 149-171. https://doi.org/http://dx.doi.org/10.1111/j.1467-9817.2011. 01497.x.

[9] Selwyn, N., J. Potter and S. Cranmer, "Primary schools and ICT: Learning from pupil perspectives." 2010, London: Continuum.

[10] Ozerbas, M. A. and B.H. Erdogan, "The effect of the digital classroom on academic success and online technologies self-efficacy." 2016, Educational Technology and Society, 19(4), 203-212.

[11] Lim, C., "Effective integration of ICT in Singapore school: Pedagogical and policy implications." 2007, Education Technology Research Development, 55, 83-116. https://doi.org/10.1007/s11423-006-9025-2

[12] Lim, C., et al., "ICT in primary education." 2014, Moscow: UNESCO.

[13] Riley, K., "Walking the leadership tightrope: building community cohesiveness and social capital in schools in highly disadvantaged urban communities." 2013, British Education Research Journal, 39(2), 266-286.

[14] Gibson, K., et al., "Child poverty and mental health: A literature review." 2017, Wellington: Child Poverty Action Group, The New Zealand Psychological Society.

[15] Simpson, J., M. Duncanson, G. Oben, G. and A. Wicken, "Child Poverty Monitor 2016 Technical Report." 2016, Dunedin: NZ Child and Youth Epidemiology Service, University of Otago.

[16] Martin, R., "Te Whakarauora Reo Nō Tuawhakarere Giving our children what we missed out on: Māori language revitalisation for Māori/English bilingualism,” 2017, University of Canterbury, Christchurch). Retrieved from http://hdl.handle.net/10092/13291. 